MATEC Web of Conferences 47, 01010 (2016)

DOI: $10.1051 /$ matecconf/20164701010

(C) Owned by the authors, published by EDP Sciences, 2016

\title{
Fresh Properties and Flexural Strength of Self-Compacting Concrete Integrating Coal Bottom Ash
}

\author{
Norwati Jamaluddin ${ }^{1}$, Ahmad Farhan Hamzah ${ }^{1,5}$, a , Mohd Haziman Wan Ibrahim ${ }^{1}$, Ramadhansyah \\ Putra Jaya ${ }^{2}$, Mohd Fadzil Arshad ${ }^{3}$, Norul Ernida Zainal Abidin ${ }^{1}$ and Nurol Huda Dahalan ${ }^{4}$ \\ ${ }^{1}$ Faculty of Civil and Environmental Engineering, Universiti Tun Hussein Onn Malaysia, 86400 Parit Raja, Johor, \\ Malaysia \\ ${ }^{2}$ Faculty of Civil Engineering, Universiti Teknologi Malaysia, 81310 Skudai, Johor, Malaysia \\ ${ }^{3}$ Faculty of Civil Engineering, Universiti Teknologi MARA, 40450 Shah Alam, Selangor, Malaysia \\ ${ }^{4}$ Faculty of Civil Engineering, Universiti Teknologi MARA, 13500 Permatang Pauh, Pulau Pinang, Malaysia \\ ${ }^{5}$ National Hydraulic Research Institute of Malaysia, 43300 Seri Kembangan, Selangor, Malaysia
}

\begin{abstract}
This paper presents the effect of using coal bottom ash as a partial replacement of fine aggregates in self-compacting concrete (SCC) on its fresh properties and flexural strength. A comparison between SCC with various replacements of fine aggregates with coal bottom ash showed that SCC obtained flexural strength decrease on increase of water cement ratio from 0.35 to 0.45 . The natural sand was replaced with coal bottom ash up to $30 \%$ volumetrically. The fresh properties were investigated by slump flow, $\mathrm{T}_{500}$ spread time, L-box test and sieve segregation resistance in order to evaluate its self-compatibility by compared to control samples embed with natural sand. The results revealed that the flowability and passing ability of SCC mixtures are decreased with higher content of coal bottom ash replacement. The results also showed that the flexural strength is affected by the presence of coal bottom ash in the concrete. In addition, the water cement ratios are influence significantly with higher binder content in concrete.
\end{abstract}

\section{Introduction}

Self-Compacting Concrete also referred as SCC is highly workable concrete that can flow through densely reinforced and complex structural elements under its own weight. It can fill all voids with no segregation, excessive bleeding and air migration air-popping, or other separation of materials, and without the need for vibration or other mechanical consolidation [1]. In early 1990's, SCC technology had been developed in Japan. Currently, this concrete has gained extensive use in many countries including Malaysia for different applications and structural configuration [1, 2]. It is agreed that SCC enhanced concrete stability and involves the effect of different mixture variables to certify satisfactory fresh properties and excellent mechanical properties especially compressive strength [2]. The challenge in SCC is to achieve good strength concrete with economical cost, as compared with conventional concrete, which is used high quantity of Portland cement and chemical admixtures [3]. An approach to reduce the cost with mineral admixtures, the utilization of supplementary cementitious materials is applicable in SCC due to durability developments potential in the concrete composite and

\footnotetext{
${ }^{\mathrm{a}}$ Corresponding author : ahmadfarhanhamzah@gmail.com
} 
overall economy. In addition, the inclusion of mineral admixtures is able to sustain workability and long-term properties [4].

In principle, the materials employed in the concrete are appropriate to be utilized in making of SCC including mineral admixture such as silica fume and fly ash, granulated blast furnace slag, etc. Meanwhile, several studies have been found to investigate the performance of SCC incorporating byproduct waste material [5-7]. However, the research on bottom ash in the SCC is limited. Though a large number of significant results have been reported on the use of coal bottom ash in concrete, there is not much literature available on the use of coal bottom ash as a fine aggregate replacement material in SCC [8,9]. Malaysia has established 4 electrical power plants that use a coal fired as power material must have a good dumping system to control the waste which composed of $80 \%$ of fly ash and $20 \%$ of bottom ash. As the dumping area is limited and become serious problem to environments, coal bottom ash is suggested to be used in concrete making which the result of utilization perhaps positively reduce the particular problem. This paper presents the flexural strength development of SCC with coal bottom ash as a fractional auxiliary of fine aggregates. The authors indicated the results in the form of mechanical strength test with three water cement ratios and different replacement level of coal bottom ash at the age of 28,90 and 180 days.

\section{Experimental Program}

\subsection{Material}

In the current study, Portland Fly Ash cement used as a main binder. The fine aggregates were coal bottom ash and river sand. The coal bottom ash was collected from one of the coal-fired power plant in Malaysia and has a fine classified size distribution within the range of $0.075 \mathrm{~mm}$ to $20 \mathrm{~mm}$. The coarse aggregates were graded size sieved through $16 \mathrm{~mm}$ and retained at $10 \mathrm{~mm}$, meanwhile for fine aggregates were graded size sieved through $5 \mathrm{~mm}$. Both river sand and coarse aggregate have a specific gravity of 2.61 and 2.67 respectively. The polymer-based superplasticizer has a specific gravity of 1.09 with $\mathrm{pH} 5.29$ which is used to magnify the fresh concrete workability. The physical and chemical properties of cement and coal bottom ash is given in Table 1. The total composition $\left(\mathrm{SiO}_{2}+\mathrm{Al}_{2} \mathrm{O}_{3}+\mathrm{Fe}_{2} \mathrm{O}_{3}\right)$ in coal bottom ash exceeded $70 \%$, indicating that it can be classified as class $\mathrm{F}$ ash as specified in ASTM C 618 [10]. In terms of chemical, coal bottom ash is considered as a pozzolonic material same as Portland and fly ash cement. Figure 1 shows the coal bottom ash particle size spreading and natural sand.

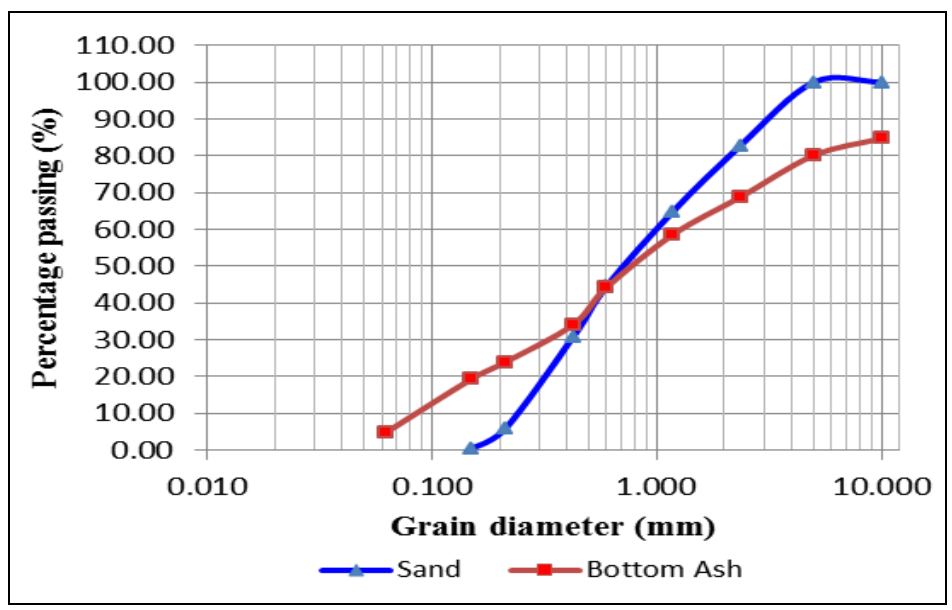

Figure 1. Particle size analysis. 
Table 1. Chemical composition of cement and coal bottom ash.

\begin{tabular}{|c|c|c|c|c|c|c|c|c|c|c|c|c|c|}
\hline \multirow{2}{*}{ Content } & \multicolumn{10}{|c|}{ Chemical composition (\%) } & \multirow{2}{*}{$\begin{array}{l}\text { Loss on } \\
\text { ignition }\end{array}$} & \multirow{2}{*}{$\begin{array}{l}\text { Specific } \\
\text { gravity }\end{array}$} & \multirow{2}{*}{$\begin{array}{r}\text { Moisture } \\
\text { Content }\end{array}$} \\
\hline & $\mathrm{SiO}_{2}$ & $\mathbf{A l}_{2} \mathbf{O}_{3}$ & $\mathrm{Fe}_{2} \mathrm{O}_{3}$ & $\mathrm{CaO}$ & $\mathbf{K}_{2} \mathbf{O}$ & $\mathrm{TiO}_{2}$ & $\mathrm{MgO}$ & $\mathrm{Na}_{2} \mathrm{O}$ & $\mathrm{CO}_{2}$ & MnO & & & \\
\hline $\begin{array}{l}\text { Coal bottom } \\
\text { ash }\end{array}$ & 68.9 & 18.7 & 6.5 & 1.61 & 1.52 & 1.33 & 0.53 & 0.24 & 0.1 & - & 2.68 & 1.72 & $40 \%$ \\
\hline Cement & 22 & 8.35 & 3.92 & 58.9 & 1.01 & 0.72 & 0.52 & 0.26 & 0.1 & 0.15 & 1.72 & 3.0 & - \\
\hline
\end{tabular}

\subsection{Mix proportions and preparation of samples}

Mix proportion was referred to Jawahar et al. [11]. The mix proportions of the constituent are given in Table 2. The water/cement ratios of $0.35,0.40$ and 0.45 concrete mixtures were considered in six batches volumetric replacement proportion of fine aggregate with coal bottom ash ranged from $0 \%$ to $30 \%$. The fine aggregate comprise was preserved at $45 \%$ by volume of mortar and coarse aggregate was preserved at $28 \%$ by volume of concrete, while air-content being assumed to be $2 \%$. The amount of super plasticizers was adjusted until the concrete achieve self-compatibility.

In order to ensure the concrete mixture in SCC classification, fresh properties of the concrete mixture was tested. The slump flow, slump flow time $\left(\mathrm{T}_{500}\right)$, L-box blocking ratio and segregation resistance ratio test were executed to determine the fresh properties of the mixtures. All procedure conducting the tests was referred to British Standards [12-14]. The prism size of $100 \times 100 \times 500 \mathrm{~mm}$ was used and flexural strength was tested at age 28, 90 and 180 days.

Table 2. Mix proportions in $\mathrm{kg} / \mathrm{m}^{3}$.

\begin{tabular}{cccccccc}
\hline Mix & $\begin{array}{c}\text { w/c } \\
\text { ratio }\end{array}$ & Cement & $\begin{array}{c}\text { Coarse } \\
\text { Aggregates }\end{array}$ & $\begin{array}{c}\text { Fine } \\
\text { Aggregates }\end{array}$ & $\begin{array}{c}\text { Coal Bottom } \\
\text { Ash }\end{array}$ & Water & $\begin{array}{c}\text { SP } \\
\text { (\%) }\end{array}$ \\
\hline \multirow{3}{*}{ BA0 } & 0.35 & 557 & 715.5 & 874.50 & 0 & 194.95 & 0.17 \\
& 0.40 & 518 & 715.5 & 874.50 & 0 & 207.20 & 0.16 \\
& 0.45 & 485 & 715.5 & 874.50 & 0 & 218.25 & 0.16 \\
BA10 & 0.35 & 557 & 715.5 & 787.05 & 87.45 & 194.95 & 0.23 \\
& 0.40 & 518 & 715.5 & 787.05 & 87.45 & 207.20 & 0.20 \\
& 0.45 & 485 & 715.5 & 787.05 & 87.45 & 218.25 & 0.19 \\
BA15 & 0.35 & 557 & 715.5 & 743.33 & 131.175 & 194.95 & 0.28 \\
& 0.40 & 518 & 715.5 & 743.33 & 131.175 & 207.20 & 0.26 \\
& 0.45 & 485 & 715.5 & 743.33 & 131.175 & 218.25 & 0.21 \\
BA20 & 0.35 & 557 & 715.5 & 699.60 & 174.90 & 194.95 & 0.36 \\
& 0.40 & 518 & 715.5 & 699.60 & 174.90 & 207.20 & 0.32 \\
& 0.45 & 485 & 715.5 & 699.60 & 174.90 & 218.25 & 0.30 \\
BA25 & 0.35 & 557 & 715.5 & 655.88 & 218.625 & 194.95 & 0.17 \\
& 0.40 & 518 & 715.5 & 655.88 & 218.625 & 207.20 & 0.16 \\
& 0.45 & 485 & 715.5 & 655.88 & 218.625 & 218.25 & 0.16 \\
BA30 & 0.35 & 557 & 715.5 & 612.15 & 262.35 & 194.95 & 0.23 \\
& 0.40 & 518 & 715.5 & 612.15 & 262.35 & 207.20 & 0.20 \\
\hline
\end{tabular}

\section{Results}

\subsection{Fresh properties}

The results of fresh characteristic of mixtures such as slump flow, slump spread time $\left(\mathrm{T}_{500}\right)$, L-box ratio and segregation resistance are presented as shown in Table 3. The slump flow values for all water cement ratios were known within the ranged of 550-750 $\mathrm{mm}$ while $\mathrm{T}_{500}$ spread times were in ranged between 2.5 and 5 seconds. The flowability of mixtures was reduced significantly with an 
increase of coal bottom ash. The decreased of slump flow values are due to the porosity of coal bottom ash in concrete, thus absorbed more fluid with higher content of coal bottom ash. The result is affected by irregular shape of coal bottom ash that reducing aggregates inter-particle friction and indicates by combining coal bottom ash reduces the viscosity of SCC mixtures $[2,15,16]$. In the context of passing ability, the L-box blocking ratio decreased when the percentage of coal bottom ash increased from $0 \%$ to $30 \%$. The results revealed due to the aggregate crowded in front of openings, which caused from difficulty of particle to flow without obstruction. The trend is parallel as L-box test for sieve segregation test as the ratio decreased with increase coal bottom ash content. The sieve segregation results are indicated by the aggregates settlement which was reduced with higher content of coal bottom ash. As plastic viscosity decreases the settlement rate of coarse aggregate, thus it is improves the segregation resistance of fresh concrete [17].

Table 3. The fresh properties of self-compacting concrete.

\begin{tabular}{|c|c|c|c|c|c|c|c|c|c|}
\cline { 2 - 11 } \multicolumn{1}{c|}{} & \multicolumn{3}{c|}{ BA0 } & \multicolumn{3}{c|}{ BA10 } & \multicolumn{3}{c|}{ BA15 } \\
\hline Water cement ratio & $\mathbf{0 . 3 5}$ & $\mathbf{0 . 4 0}$ & $\mathbf{0 . 4 5}$ & $\mathbf{0 . 3 5}$ & $\mathbf{0 . 4 0}$ & $\mathbf{0 . 4 5}$ & $\mathbf{0 . 3 5}$ & $\mathbf{0 . 4 0}$ & $\mathbf{0 . 4 5}$ \\
\hline Slump flow (mm) & 700 & 720 & 745 & 670 & 710 & 725 & 650 & 688 & 708 \\
\hline $\mathbf{T}_{\mathbf{5 0 0}}(\mathbf{s})$ & 2.87 & 2.59 & 2.32 & 3.1 & 2.84 & 2.55 & 3.71 & 3.31 & 2.87 \\
\hline L-box ratio & 0.97 & 0.94 & 0.90 & 0.92 & 0.89 & 0.81 & 0.92 & 0.86 & 0.80 \\
\hline SR (\%) & 9.61 & 9.85 & 10.37 & 7.93 & 8.15 & 9.25 & 6.61 & 7.83 & 8.13 \\
\hline & \multicolumn{3}{|c|}{ BA20 } & \multicolumn{3}{c|}{ BA25 } & \multicolumn{3}{c|}{ BA30 } \\
\hline Water cement ratio & $\mathbf{0 . 3 5}$ & $\mathbf{0 . 4 0}$ & $\mathbf{0 . 4 5}$ & $\mathbf{0 . 3 5}$ & $\mathbf{0 . 4 0}$ & $\mathbf{0 . 4 5}$ & $\mathbf{0 . 3 5}$ & $\mathbf{0 . 4 0}$ & $\mathbf{0 . 4 5}$ \\
\hline Slump flow (mm) & 615 & 635 & 685 & 588 & 600 & 648 & 545 & 570 & 625 \\
\hline T $_{\mathbf{5 0 0}}(\mathbf{s})$ & 4.26 & 3.9 & 3.05 & 4.53 & 4.18 & 3.77 & 4.87 & 4.57 & 4.02 \\
\hline L-box ratio & 0.88 & 0.80 & 0.77 & 0.88 & 0.80 & 0.70 & 0.76 & 0.69 & 0.66 \\
\hline SR (\%) & 5.24 & 6.06 & 6.72 & 5.20 & 6.28 & 6.58 & 5.50 & 6.20 & 6.51 \\
\hline
\end{tabular}

\subsection{Flexural strength}

The results of flexural strength are shown in Figure 2, Figure 3 and Figure 4. It is obvious that the flexural strength of $10 \%$ replacement of coal bottom ash is higher compared to control sample for all water cement ratios. The development was observed at the age of 28, 90 and 180 days. As for the sample with 0.35 water cement ratio, the mixture of BA10 shows increment of $1.58 \%, 2.85 \%$ and $9.2 \%$ at respective ages.

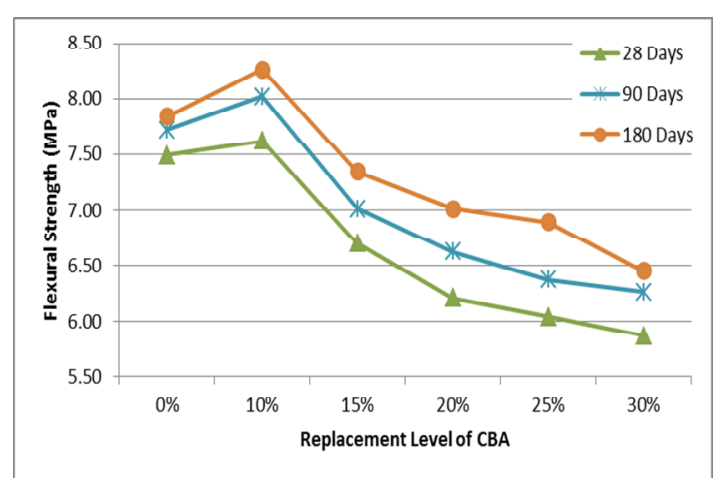

Figure 2. Flexural strength for 0.35 water cement ratios.

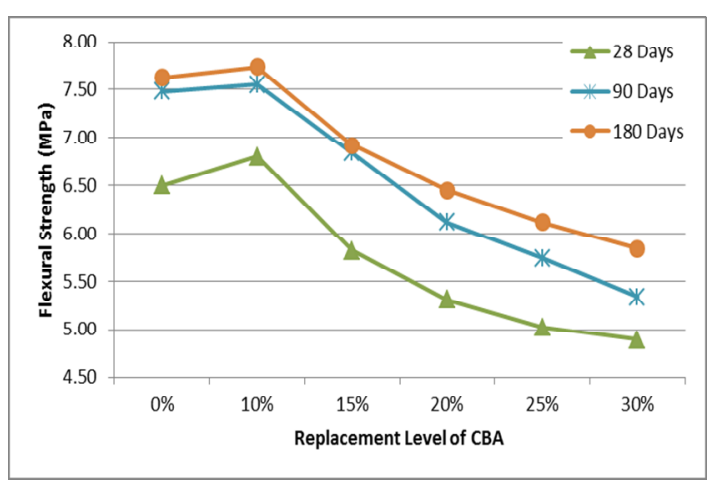

Figure 3. Flexural strength for 0.40 water cement ratios. 


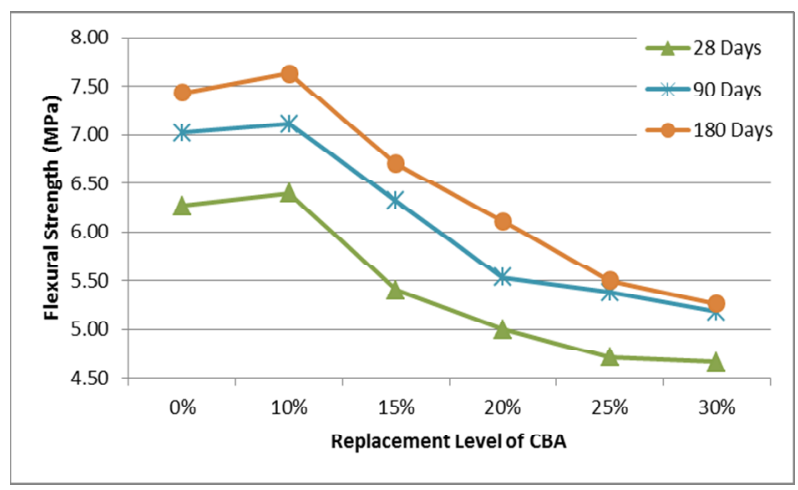

Figure 4. Flexural strength for 0.45 water cement ratios.

The results also determined that the increments of mixture BA10 mixture for 0.40 water cement ratio are $4.41 \%, 13.91 \%$ and $15.91 \%$ at 28,90 and 180 days, correspondingly. Meanwhile for 0.45 water cement ratio, the increments of $2.03 \%, 11.81 \%$ and $17.82 \%$ were recorded. Conversely, the flexural strength of samples reduced when $15 \%, 20 \%, 25 \%$ and $30 \%$ replacement of coal bottom ash were used in the concrete for all water cement ratios. It is marked that as the replacement level of coal bottom ash increased, the degree of flexural strength decreased gradually. The decreasing of flexural strength in the particular samples was cause by the poor joining between aggregates. The results of flexural strength in this study were found to be complement to a study conducted by Aggarwal et al. [17] and Zainal Abidin et al. [2].

\section{Conclusions}

Based on the results obtained, it is confirmed that there are significant effect of coal bottom ash to the fresh properties of the concrete. The fresh properties of SCC mixtures such as slump flow, L-box blocking ratio, and segregation resistance are decreased with the higher content of coal bottom ash replacement. Workability of the concrete mixture was reduced proportionally to the reduction of water cement ratio in the mixture. In addition, the mechanical flexural strength of mixtures decreases as a result of increasing the coal bottom ash replacement and the amount of water cement ratio; thus reduces the viscosity of the mixtures. Meanwhile, the factor of water cement ratios is influenced significantly with higher binder content.

\section{Acknowledgement}

The authors thankfully acknowledge the Fundamental Research Grant Scheme (No. Vot 1454) funded by Ministry of Higher Education Malaysia and Faculty Civil and Environmental Engineering, University Tun Hussein Onn Malaysia (UTHM).

\section{References}

[1] H. Okamura and M. Ouchi, Self-compacting concrete, Journal of Advanced Concrete Technology, 1(1), 5-15, (2003).

[2] N.E. Zainal Abidin, M.H. Wan Ibrahim, N. Jamaluddin, K. Kamaruddin and A.F. Hamzah, The effect of bottom ash on fresh characteristic, compressive strength and water absorption of selfcompacting concrete, Applied Mechanics and Materials, 660, 145-151, (2014). 
[3] N. Bouzouba and M. Lachemi, Self-compacting concreting high volumes of class F fly ash preliminary results, Cement and Concrete Research, 31, 413-420, (2001).

[4] A.F. Hamzah, M.H. Wan Ibrahim, N. Jamaluddin, R.P. Jaya and N.E. Zainal Abidin, Cementitious materials usage in self-compacting concrete: A review, In Advanced Materials Research, 1113, 153-160, (2015).

[5] F.A. Sabet, N.A. Libre and M. Shekarchi, Mechanical and durability properties of selfconsolidating high performance concrete incorporating natural zeolite, silica fume and fly ash, Construction Building Materials, 44, 175-184, (2013).

[6] M. Nepomuceno, L. Oliveira and S.M.R. Lopes, Methodology for mix design of the mortar phase of self-compacting concrete using different mineral additions in binary blends of powders, Construction Building Materials, 26(1), 317-326, (2012).

[7] M. Najimi, J. Sobhani, B. Ahmadi and M. Shekarchi, An experimental study on durability properties of concrete containing zeolite as a highly reactive natural pozzolan, Construction Building Materials, 35, 1023-1033, (2012).

[8] R. Kasemchaisiri and S. Tangtermsirikul, Properties of self-compacting concrete in corporating bottom ash as a partial replacement of fine aggregate, Science Asia, 34, 87-95, (2008).

[9] Mohd Syahrul Hisyam Mohd Sani, Fadhluhartini Muftah and Zulkifli Muda, The properties of special concrete using bottom ash (WBA) as partial sand replacement, International Journal of Sustainable Construction Engineering and Technology, 2, 65-76, (2010).

[10]ASTM C618-15, Standard Specification for Coal Fly Ash and Raw or Calcined Natural Pozzolan for Use in Concrete, ASTM International, West Conshohocken, (2015).

[11]J.G. Jawahar, C. Sashidhar, I.R. Reddy and J.A. Peter, A simple tool for self compacting concrete mix design, International Journal Advance Engineering Technology, 3(2), 550-558, (2012).

[12]BS EN12350-Part 8:2010, Testing Fresh Concrete - Self-Compacting Concrete - Slump flow test.

[13]BS EN12350-Part 10:2010, Testing Fresh Concrete - Self-Compacting Concrete - L box test.

[14]BS EN12350-Part 11:2010 Testing Fresh Concrete - Self-Compacting Concrete - Sieve segregation test.

[15]R. Siddique, P. Aggarwal and Y. Aggarwal, Influence of water or powder ratio on strength properties of self-compacting concrete containing coal fly ash and bottom ash, Construction Building Material, 29, 73-81, (2012).

[16]Abdul Kadir, Aeslina and Mohd Ikhmal Haqeem Hassan, Leachability of self-compacting concrete (SCC) incorporated with fly ash and bottom ash by using synthetic precipitation leaching procedure (SPLP), Applied Mechanics and Materials, 773, 1375-1379, (2015).

[17]P. Aggarwal, Y. Aggarwal and S.M. Gupt, Effect of bottom ash as replacement of fine aggregates in concrete, Asian Journal of Civil Engineering (Building and Housing), 8(1), 49-62,(2007). 